\title{
EVALUATION OF NUTRITIONAL STATUS AND THE LEVEL OF PHYSICAL FITNESS OF MILITARY FLYING PERSONNEL STAYING AT THE TRAINING CAMP
}

\author{
Agata GAŹDZIŃSKA ${ }^{1}$, Paweł JAGIELSKI ${ }^{2}$, Paulina BARAN ${ }^{3}$ \\ ${ }^{1}$ Laboratory of Dietetics and Obesity Treatment, Department of Pathophysiology and Flight Safety, Military \\ Institute of Aviation Medicine, Warsaw, Poland \\ ${ }^{2}$ Department of Nutrition and Drug Research, Faculty of Health Science, Jagiellonian University, Medical \\ College, Cracow, Poland \\ ${ }^{3}$ Department of Flight Simulator Innovations, Military Institute of Aviation Medicine, Warsaw, Poland
}

Source of support: Own sources

Author's address: A. Gaździńska, Military Institute of Aviation Medicine, ul. Krasińskiego 54/56, 01-755 Warsaw, Poland, e-mail: agazdzinska@wiml.waw.pl

Introduction: The aim of the conducted research was to assess the nutritional status and level of physical fitness of the military flying personnel staying at the three-week training camp in Zakopane-Gronik.

Material and The research involved 90 members of the military flying personnel staying on a threemethods: -week camp in the Military Training and Fitness Centre (WOSzK) in Zakopane. The mean age of the respondents was $34.57 \pm 7.14$ years. At the beginning and at the end of the camp period the body composition was measured and anthropometric tests were performed. In order to assess physical fitness, the scores from a physical fitness test carried out on the last day of the camp were used.

Results: During the training and fitness camp period, significant improvements $(p<0.05)$ were observed in the nutritional status of military flying personnel, including the content of body fat $(20.14 \pm 4.02$ vs. $19.50 \pm 3.89 \%)$, visceral fat $(6.48 \pm 2.79$ vs. $6.16 \pm 2.65)$, muscle mass $(61.23 \pm 5.61 \mathrm{vs} .61 .77 \pm 5.61 \mathrm{~kg})$, total body water $(44.59 \pm 3.70 \mathrm{vs} .44 .75 \pm 4.42 \mathrm{~kg})$ and waist circumference $(88.51 \pm 6.78$ vs. $87.18 \pm 6.72 \mathrm{~cm})$, and basal metabolism (1891.5 \pm 78.5 vs. $1903.9 \pm 177.3 \mathrm{kcal}) .62 .2 \%$ of the examined participants of the camp obtained a very good final score in the fitness test in all of the disciplines assessed, which indicates their high physical fitness. The soldiers who obtained a very good final score from the exam were younger $(33.39 \pm 7.08$ vs $36.50 \pm 6.92 ; p<0.05)$ and had lower content of body fat $(18.73 \pm 3.89$ vs $20.77 \pm 3.53 ; p<0.05)$ compared to those who obtained a good final score.

Figures: 3 • Tables 3 • References: 14 • Full-text PDF: http://www.pjambp.com • Copyright @ 2018 Polish Aviation Medicine Society, ul. Krasińskiego 54/56, 01-755 Warsaw, license WIML • Indexation: Index Copernicus, Polish Ministry of Science and Higher Education 
Conclusions: In connection with the improvement of nutritional parameters of the military flying personnel, as well as their high physical fitness shown in the study, it should be concluded that training and fitness camps play an important role in maintaining high psychophysical fitness of the participants.

Keywords: nutritional status, physical fitness, training camp, military flying personnel

\section{INTRODUCTION}

Proper nutritional status is one of the basic factors for maintaining high psychophysical fitness and good health of members of military flying personnel.

The nutritional status of the organism is understood as the health condition resulting from the usual consumption of food, including the absorption and utilization of the nutrients contained therein, as well as from the influence of pathological factors on these processes [4]. Although the nutritional status of the body is influenced by various factors, i.e. genetic, environmental and psychological factors [13], it is essential to maintain a proper energy balance, i.e. to ensure a balance between the energy and nutritional value of the food consumed and the amount of energy expenditure required for everyday life activity.

In order to assess the nutritional status, it is common to conduct anthropometric tests and to use the non-invasive bioelectrical impedance analysis (BIA), determining, among others, body fat mass (FM), fat-free body mass (FFM) and total body water (TBW) [5].

In military aviation, much attention is paid to issues related to the proper preparation of military flying personnel for performing tasks in the air. Maintaining proper nutritional status of the body, and consequently high efficiency and psychophysical fitness increases the body's tolerance to adverse environmental factors and, consequently, allows to extend the period of service. One of the very unfavorable phenomena that should be counteracted in members of military flying personnel is the so-called hypokinetic syndrome, which consists in limiting their mobility. Counteracting this type of phenomena is one of many tasks of the Military Training and Fitness Centres (WOSZK), to which military pilots and other flying personnel must come once a year. The centres, where three-week training camps are organized, have a rich sports base, including swimming pools, gyms, various sports grounds, climbing walls, as well as highly qualified staff. The assessment of the level of physical fitness of the participants is carried out at the end of the camp in the form of a physical test. The aim of the examination is to assess the muscle endurance, speed, dynamic strength and agility of the participant.

The stay of members of the military flying personnel in the Military Training and Fitness Centres is primarily aimed at regenerating their physical strength and improving their psychophysical resistance. The role of the centres should also be to improve the nutritional parameters of the trained soldiers with a properly designed training plan and correctly composed and balanced meals during the camp.

The aim of the conducted research was to assess the nutritional status and level of physical fitness of the military flying personnel staying at the three-week training camp in Zakopane-Gronik.

\section{MATERIAL AND METHODS}

\section{Characteristics of the test group}

The research was carried out among military flying personnel staying at the Military Training and Fitness Centre in Zakopane-Gronik for three weeks. The research was conducted in 2014. The study group consisted of 90 men. The average age of the participants was $34.57 \pm 7.14$ years, average body mass $80.97 \pm 8.33 \mathrm{~kg}$, average height 177.44 $\pm 6.39 \mathrm{~cm}$ and average BMI $25.74 \pm 2.52 \mathrm{~kg} / \mathrm{m}^{2}$.

The research was voluntary, the soldiers gave their informed consent for participation in it. The research was approved by the Ethics Committee which issues opinions on biomedical research at the Military Institute of Aviation Medicine in Warsaw (Decision No. 03/2015).

\section{Measurement methods}

At the beginning and at the end of the camp, the military flying personnel were subjected to the following tests:

1. Measurement of body composition (including body fat, fat-free body mass, total body water and basal metabolism) using the bioelectrical impedance method, with the use of Tanita SC330 analyzer (produced in Japan). The subjects were fasted, in underwear only. 
2. Assessment of the degree of overweight and obesity based on the BMI (Body Mass Index) and body fat content, according to the criteria of the World Health Organization (WHO) [14].

3. Anthropometric measurements, including height, body mass, waist and hip circumference. In order to assess physical fitness, the scores from the military fitness test for the flying personnel, carried out on the last day of their stay in the WOSZK, were used. The following sports disciplines were included in the fitness test: zigzag run (sec.), pull-ups (number), long jump (cm), sit-ups (within $2 \mathrm{~min}$.), running 10x10 m (sec.), push-ups with legs on bench (number) and swimming over $50 \mathrm{~m}$ (sec.). In order to compare the scores obtained during the fitness test with the applicable standards, the participants were divided into age groups, in accordance with the regulations applied in the Polish Army in carrying out the physical fitness test [9], namely:
a) < 30 y.o. - group I,
b) 31-35 y.o. - group II,
c) 36-40 y.o. - group III,
d) 41-45 y.o. - group IV,
e) $>46$ y.o. - group V.

All soldiers during their stay at the training camp were provided with full board, planned according to the basic board standard 040 [10].

\section{Statistical tools used}

The statistical analysis of the data was performed in PS IMAGO PRO (IBM SPSS Statistics 25). The level of statistical significance was assumed to be $p<0.05$. The normality of data distribution was verified using the Shapiro-Wilk test. Descriptive statistics were calculated for the examined variables, i.e. mean, standard deviation, median, minimum value and maximum value. The chisquare test and $U$ Mann-Whitney test were used for intergroup comparisons (final evaluation). The Wilcoxon test and McNemar-Bowker test were used to verify the significance of differences before and after the camp. Descriptive statistics are presented in tables, the calculated percentages are shown in diagrams.

\section{RESULTS}

The results of the analyses showed that during a three-week stay at a training camp most of the

Tab. 1. Assessment of the nutritional status of the flying personnel before and after the camp at the WOSzK in Zakopane-Gronik.

\begin{tabular}{|c|c|c|c|c|c|c|c|c|c|c|c|c|}
\hline \multirow[t]{2}{*}{ Parameters } & \multicolumn{6}{|c|}{ Beginning of the camp } & \multicolumn{6}{|c|}{ End of the camp } \\
\hline & $\mathbf{N}$ & $\mathbf{x}$ & SD & ME & MIN & MAX & $\mathbf{x}$ & SD & ME & MIN & MAX & $\mathbf{p}$ \\
\hline WEIGHT [kg] & 90 & 80.97 & 8.33 & 81.90 & 59.10 & 101.40 & 80.90 & 8.02 & 81.10 & 59.60 & 102.70 & 0.9250 \\
\hline BMI $\left[\mathrm{kg} / \mathrm{m}^{2}\right]$ & 90 & 25.74 & 2.52 & 26.00 & 19.10 & 32.50 & 25.72 & 2.42 & 25.90 & 19.50 & 32.10 & 0.9520 \\
\hline FATP [\%] & 90 & 20.14 & 4.02 & 20.15 & 10.20 & 33.00 & 19.50 & 3.86 & 19.50 & 9.70 & 28.40 & 0.0002 \\
\hline FATM $[\mathrm{kg}]$ & 90 & 16.46 & 4.27 & 16.60 & 6.30 & 27.40 & 15.91 & 3.99 & 16.00 & 6.40 & 26.70 & 0.0014 \\
\hline MM [kg] & 90 & 61.23 & 5.61 & 61.55 & 44.50 & 76.80 & 61.77 & 5.61 & 61.75 & 43.20 & 77.70 & 0.0003 \\
\hline VFATL & 90 & 6.48 & 2.79 & 6.50 & 1.00 & 15.00 & 6.16 & 2.65 & 6.00 & 1.00 & 13.00 & 0.0001 \\
\hline FFM [kg] & 90 & 64.48 & 5.86 & 64.75 & 46.90 & 80.80 & 64.99 & 5.84 & 64.95 & 45.50 & 80.60 & 0.0004 \\
\hline TBW $[\mathrm{kg}]$ & 90 & 44.59 & 3.70 & 44.55 & 32.80 & 55.70 & 44.75 & 4.42 & 44.55 & 21.80 & 55.50 & 0.0016 \\
\hline TBW [\%] & 90 & 55.23 & 2.56 & 54.96 & 48.62 & 62.33 & 55.32 & 4.86 & 55.59 & 16.80 & 63.61 & 0.0001 \\
\hline BMR [kcal] & 90 & 1891.5 & 178.5 & 1891.7 & 1394.5 & 2423.0 & 1903.9 & 177.3 & 1899.4 & 1361.4 & 2422.0 & 0.0018 \\
\hline METAAGE [years] & 90 & 34.09 & 11.64 & 34.00 & 12.00 & 67.00 & 32.63 & 11.11 & 32.00 & 12.00 & 67.00 & 0.0010 \\
\hline Waist circumference $[\mathrm{cm}]$ & 89 & 88.51 & 6.78 & 88.00 & 71.00 & 111.00 & 87.18 & 6.72 & 86.50 & 69.70 & 106.00 & 0.0005 \\
\hline Hip circumference $[\mathrm{cm}]$ & 89 & 96.38 & 4.09 & 96.00 & 84.00 & 105.50 & 96.72 & 4.57 & 96.75 & 84.00 & 106.70 & 0.9078 \\
\hline
\end{tabular}

$\mathrm{N}$ - number of participants, $\mathrm{X}$ - mean value, $\mathrm{SD}$ - standard deviation, $\mathrm{Me}$ - median, Min. - minimum value, Max - maximum value, $\mathrm{p}-$ Wilcoxon test score.

Weight [kg] - body mass; BMI [kg/m²] - body mass index; FATP [\%] - body fat percentage; FATM [kg] - fat mass; MM [kg] - muscle mass; VFATL - visceral fat level; FFM [kg] - fat-free body mass; TBW [kg] - total body water mass; TBW [\%] - body water percentage; BMR [kcal] - basal metabolism. 
Gaździńska A. et al. - Evaluation of nutritional ...

Tab. 2. The results obtained from the fitness test by members of the military flying personnel staying at the WOSZK in Zakopane-Gronik.

\begin{tabular}{|c|c|c|c|c|c|c|}
\hline \multirow[t]{2}{*}{ Exercises } & \multicolumn{6}{|c|}{ Total } \\
\hline & $\mathbf{N}$ & $\mathbf{x}$ & SD & Me & Min. & Max. \\
\hline Zigzag run [sec.] & 90 & 24.17 & 1.40 & 24.20 & 21.30 & 27.40 \\
\hline Pull-ups [number] & 89 & 12.40 & 6.29 & 11.00 & 2.00 & 35.00 \\
\hline Standing long jump [cm] & 90 & 231.17 & 17.96 & 235.00 & 185.00 & 280.00 \\
\hline $\begin{array}{l}\text { Sit-ups (in } 2 \text { minutes) } \\
\text { [number] }\end{array}$ & 90 & 64.93 & 17.61 & 65.00 & 33.00 & 120.00 \\
\hline Running $10 \times 10$ [sec.] & 90 & 29.12 & 1.76 & 29.10 & 23.30 & 33.40 \\
\hline Swimming [sec.] & 90 & 50.05 & 10.52 & 49.00 & 33.00 & 79.04 \\
\hline Push-ups [number] & 89 & 46.73 & 16.32 & 45.00 & 15.00 & 110.00 \\
\hline Overall score & 90 & 4.57 & 0.70 & 5.00 & 3.00 & 5.00 \\
\hline
\end{tabular}

$\mathrm{N}$ - number of participants, $\mathrm{X}$ - mean value, $\mathrm{SD}$ - standard deviation, $\mathrm{Me}$ - median, Min. - minimum value, Max. - maximum value

measured parameters of the nutritional status of military flying personnel improved significantly (tab. 1).

The data presented in table 1 indicate that the mean total body fat content, visceral fat content, as well as the waist circumference of the examined participants $(p<0.05)$ have significantly decreased. However, the average body water content, muscle mass and basal metabolism increased significantly $(p<0.05)$.

There were no significant changes in the value of BMI of the participants over the course of the camp (fig. 1).

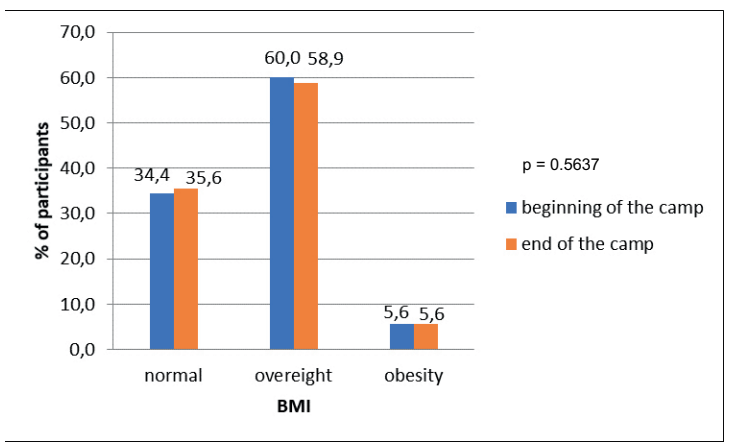

Fig. 1. Percentage distribution of the BMl of the flying personnel flying before and after the camp at the WOSzK in Zakopane-Gronik.

$\mathrm{p}$-chi-square test result

The percentage of people with overweight and obesity according to the BMI was similar at the beginning and at the end of the camp, as shown in figure 1. However, the percentage of people with normal body fat content increased significantly from $43 \%$ to $51 \%$, while the percentage of people with body fat content indicating overweight and obesity decreased (fig. 2).

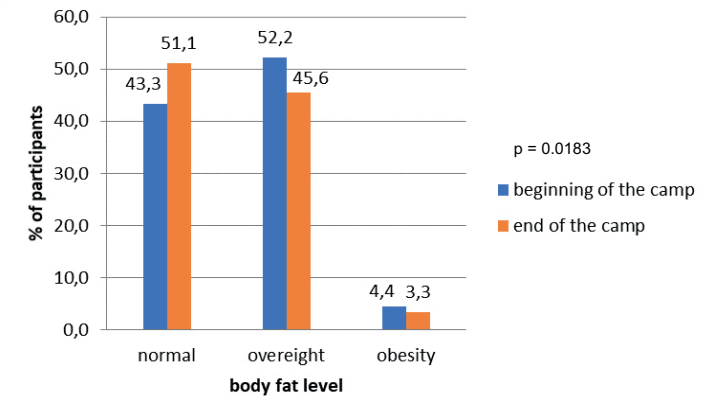

Fig. 2. Percentage distribution of the interpretation of the body fat content of the flying personnel before and after the camp at the WOSzK in Zakopane-Gronik.

$\mathrm{p}$ - chi-square test result

The scores obtained by the participants of the training camp are presented in table 2 .

$62.2 \%$ of the examined participants of the camp obtained a very good final grade in the fitness test in all of the disciplines assessed. This grade decreased with the age of the examined soldiers, as shown in figure 3 .

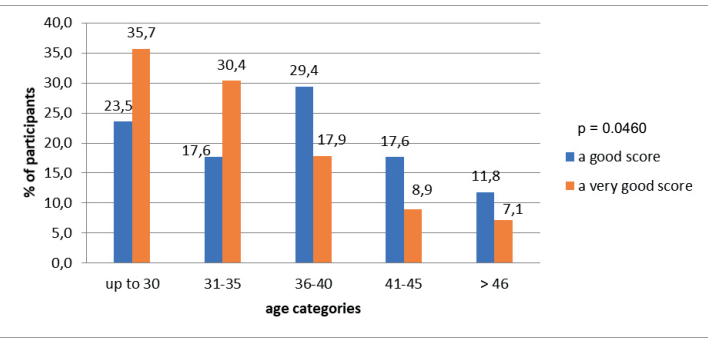

Fig. 3. The final grade for the exam by age group. $\mathrm{p}$-chi-square test result

The analysis of the test results also revealed significant differences in the overall scores from the fitness test obtained by the participants of the camp, differentiated in terms of the body fat percentage. Those who obtained a very good score 
Tab. 3. The results of anthropometric measurements of the flying personnel staying at the WOSZK in Zakopane-Gronik depending on the final score from the fitness test.

\begin{tabular}{cccccccccccccc}
\hline & \multicolumn{1}{c}{ Good score } & \multicolumn{1}{c}{ Very good score } \\
\cline { 2 - 14 }$y$ & $\mathbf{N}$ & $\mathbf{X}$ & SD & Me & Min. & Max. & N & X & SD & Me & Min. & Max. & p \\
\hline Age [years] & 34 & 36.50 & 6.92 & 37.00 & 24.00 & 52.00 & 56 & 33.39 & 7.08 & 33.00 & 24.00 & 53.00 & $\mathbf{0 . 0 4 0 7}$ \\
\hline Body weight [kg] & 34 & 80.27 & 8.56 & 79.60 & 59.60 & 98.40 & 56 & 81.28 & 7.72 & 81.70 & 62.00 & 102.70 & 0.6712 \\
\hline BMI [kg/m²] & 34 & 25.93 & 2.35 & 26.15 & 19.50 & 30.70 & 56 & 25.59 & 2.48 & 25.70 & 20.20 & 32.10 & 0.3364 \\
\hline FATP [\%] & 34 & 20.77 & 3.53 & 20.65 & 10.60 & 28.40 & 56 & 18.73 & 3.89 & 19.20 & 9.70 & 28.40 & $\mathbf{0 . 0 0 8 6}$ \\
\hline FATM [kg] & 34 & 16.77 & 3.66 & 16.50 & 6.40 & 25.90 & 56 & 15.39 & 4.13 & 16.00 & 7.20 & 26.70 & 0.0903 \\
\hline MM [kg] & 34 & 60.41 & 6.20 & 60.50 & 43.20 & 75.40 & 56 & 62.59 & 5.10 & 62.05 & 48.10 & 77.70 & 0.0703 \\
\hline
\end{tabular}

from the fitness test at the end of the camp had a lower body fat content compared to those who obtained a good score $(p=0.009)$, as shown in table 3 .

\section{DISCUSSION}

Physical fitness, as well as nutritional status, are linked to health, which is why the Polish Army devotes much attention to them. The requirements for military pilots concerning general physical fitness and performance are very high. The way to improve and achieve the optimum level of fitness and performance parameters of military flying personnel is a regular training oriented to general and specialist preparation. These functions are carried out, among others, in the WOSZK in Zakopane-Gronik.

The assessment of nutritional status indicates whether the physiological needs of the examined person are met in relation to their nutritional requirements. The research on the nutritional status of the Polish Army soldiers carried out for years shows the occurrence of overweight and obesity both in soldiers beginning their military service, and in those serving in the army for many years. According to the research carried out by scientists from the Military Institute of Aviation Medicine in Warsaw, overweight and obesity assessed on the basis of body fat content were found in respectively $21.6 \%$ and $16.2 \%$ of 4 th and 5 th year students of the Air Force Academy [3]. In other studies, conducted on a group of 172 military pilots, obesity was found in $5.2 \%$ of soldiers [2].

Research on the nutritional status of military flying personnel published in 2008 by the team from the Military Institute of Hygiene and Epidemiology on the basis of BMI analysis showed the occurrence of overweight in a smaller number of participants $(50 \%)$ compared to the authors' research presented in this paper. Obesity, on the other hand, was found in a higher percentage of respondents, i.e. $10.5 \%$ in the age group up to 30 years and $18.9 \%$ of older respondents [6].

Bertrandt and Kłos, when examining a group of military flight engineers and navigators based on the BMI index, found overweight in $45 \%$ and $54 \%$ of them respectively, while obesity was observed in $24 \%$ of engineers and $22 \%$ of navigators [1]. Taking into account the assessment of the BMI, overweight was also observed in $80 \%$ of the GROM soldiers. No obesity was found in this group. However, the authors of the study indicate the occurrence of overweight resulting from muscles, as the body fat percentage was within acceptable standards [11].

In the study of the nutritional status of the soldiers of the Representative Honor Guard Regiment of the Polish Armed Forces, the highest number of soldiers with overweight (BMl $>25 \mathrm{~kg} /$ $\mathrm{m}^{2}$ ) was found in the group aged $26-30-60.8 \%$, and the lowest in the group of the oldest soldiers over $40-42.8 \%$. The oldest age group recorded the highest number of obese soldiers (BMI $>30$ $\left.\mathrm{kg} / \mathrm{m}^{2}\right)-28.6 \%$, while in the younger age group (31-40) almost every 10th soldier was obese (9.1\%). The lowest percentage of obesity was observed in younger soldiers (5.0\%) [8].

In the study on the nutritional status of 123 soldiers serving in one of the units of chemical troops, half of the examined soldiers in the group of up to 30 years old were found to have normal body mass, while in the group of older soldiers the percentage of people with normal body mass (BMI in the range $18.5-24.9 \mathrm{~kg} / \mathrm{m}^{2}$ ) was lower and amounted to $46.4 \%$ [7].

In the above-mentioned works, researchers evaluated body mass disorders based primarily on the BMI. However, it should be remembered that despite its simplicity and frequent use in studies on nutritional status, this index is burdened by an error because it does not take into account the body composition of the examined person and therefore may lead to misinterpretation of the re- 
sults, especially in people with extensive muscle mass.

Based on the conducted research, it should be concluded that the nutritional status of the examined military flying personnel is not fully satisfactory, as excessive body weight according to the BMI was found in over $60 \%$ of the examined persons, while excessive body fat content was observed in over $50 \%$ of the participants (fig. 1 and fig. 2).

As far as the level of physical fitness of the military flying personnel is concerned, the conducted research has shown that the soldiers received good and very good scores for particular physical fitness tests, according to the system of scores adopted in the Polish Army. Similar results were obtained by Tomczak et al. [12], assessing the level of physical fitness of air cavalry soldiers. In addition, the study revealed that those who received a very good final score from the fitness test were younger and had a lower body fat content compared to soldiers who received a good score. On this basis, it can be concluded that training plans should be properly designed, especially for older groups of soldiers, in order to help them maintain high physical fitness in subsequent years of service.

Comparing the results of the physical fitness assessment of the military flying personnel during the training camp with the results of the GROM soldiers, it has been demonstrated that the level of physical fitness of the soldiers of the special unit is much higher. They received a very good score in all fitness tests [11]. For example, in the situps they had 91.5 repetitions (i.e. 26.6 more repetitions) and 18.27 repetitions in pull-ups (i.e. 5.9 more repetitions). In a $10 \times 10 \mathrm{~m}$ run, however, the GROM soldiers recorded a time that was $2.9 \mathrm{sec}-$ onds worse than that of the military flying personnel examined.

To sum up, the research conducted revealed that members of military flying personnel are characterized by high physical fitness and that their body composition parameters are improved during the training camp. On this basis, it can be concluded that the Military Training and Fitness Centres perform their functions and allow to improve the overall psychophysical fitness of the military flying personnel.

\section{CONCLUSIONS}

Participation in the three-week training camp has a positive impact on the nutritional status of the military flying personnel.

The results obtained from the fitness test indicate high physical fitness of the participants of the training camp.

Due to the improvement in the nutritional status parameters observed in the respondents, as well as taking into account their high physical fitness, it can be concluded that training camps play an important role in maintaining high psychophysical fitness of the military flying personnel.

\section{AUTHORS' DECLARATION:}

Study Design: Agata Gaździńska, Paulina Baran; Data Collection: Agata Gaździńska, Paulina Baran; Manuscript Preparation: Agata Gaździńska, Paulina Baran, Paweł Jagielski. The Authors declare that there is no conflict of interest.

\section{REFERENCES}

1. Bertrandt J, Kłos A. Estimation of protein-energy and mineral nutritional status of flight engineers and navigators serving in the Polish Air Force. Military Pharmacy and Medicine 2012; 2:118-121.

2. Gaździńska A, Kłossowski M. Ocena wpływu wybranych czynników żywieniowych oraz aktywności fizycznej na występowanie nadwagi i otyłości u wojskowego personelu latającego. Polski Przegląd Medycyny Lotniczej 2006; 12(2):125-135.

3. Gaździńska A, Baran P, Skibniewski F, Truszczyński O, Gaździński S, Wyleżoł M. Częstość występowania nadwagi i otyłości u studentów lotniczej uczelni wojskowej a poziom ich aktywności fizycznej. Medycyna Pracy 2015; 66(5):653-660.

4. Gertig H, Gawęcki J. Słownik terminów żywieniowych. Warszawa: Wydawnictwo PWN; 2001.

5. Gronowska-Senger A. Zarys oceny żywienia. Warszawa: Wydawnictwo SGGW; 2009.

6. Kłos A, Bertrandt J, Kłos K. Występowanie nadwagi i otyłości wśród wojskowego personelu latającego. Polski Przegląd Medycyny Lotniczej 2008; 4:337-343. 
7. Kłos A, Bertrandt J, Łakomy R. Występowanie nadwagi i otyłości oraz ocena stanu uwapnienia kości wśród żołnierzy wybranej jednostki wojsk chemicznych. Problemy Higieny i Epidemiologii 2012; 93(4):844-847.

8. Kłos A, Bertrandt J, Tomczak A, Kłos K. Assessment of nutritional status of soldiers serving in Representative Battalion of Polish Army. Problemy Higieny i Epidemiologii 2015; 96(4):785-788.

9. Regulation of the Minister of National Defence of 12 February 2010 on the performance of physical fitness tests of professional soldiers (Journal of Laws of 2010 item 138, as amended).

10. Regulation of the Minister of National Defence of 4 December 2014 on the free boarding of professional soldiers and soldiers serving as candidates (Journal of Laws 2015 item 42).

11. Tomczak A, Bertrandt J, Kłos A, Bertrandt B. Assessment of physical fitness, physical capacity and nutritional status of soldiers serving in the „GROM" Polish Special Forces Unit. Problemy Higieny i Epidemiologii 2014; 95(1):86-90.

12. Tomczak A, Jaciubek D, Kłos A, Bolczyk I, Bertrandt J. Poziom sprawności fizycznej oraz stan odżywienia żołnierzy kawalerii powietrznej. Problemy Higieny i Epidemiologii 2019; 100(1):36-41.

13. Waluś A, Wądołowska L, Cichon R. Stan odżywienia 16-letniej młodzieży z regionu suwalskiego o różnym statusie ekonomicznym. Żywienie Człowieka i Metabolizm 2003; 30:209-215.

14. WHO. Obesity: preventing and managing the global epidemic: report of a WHO consultation. WHO Tech Rep Ser, 894. Geneva, Switzerland; 1999.

Cite this article as: Gaździńska A, Jagielski P, Baran P. Evaluation of Nutritional Status and The Level of Physical Fitness of Military Flying Personnel Staying at The Training Camp. Pol J Aviat Med Bioeng Psychol 2018; 24(3): 12-18. DOI: 10.13174/ pjambp.11.02.2020.02 